\title{
39. DISTRIBUTION OF GASES AND BITUMENS IN BASALTS FROM HOLES 395 AND 396, LEG 45
}

\author{
B. P. Zolotarev, G. I. Voitov, I. S. Sarkisyan, and L. F. Cherevichnaya, Geological Institute of the USSR, \\ Academy of Sciences, Moscow, USSR
}

Young basalts distributed in oceanic islands and island arcs are characterized by a relatively narrow range of chemical composition of gases. The total gas content in these rocks is not more than $1 \mathrm{~cm}^{3} / \mathrm{kg}$. But rocks subjected to epimagmatic changes can contain more than $10 \mathrm{~cm}^{3} / \mathrm{kg}$ of gases, mostly $\mathrm{CO}_{2}$ (Voitov et al., 1970; Zolotarev et al., 1976). The established narrow range of chemical composition and concentration of gases in basalts is a result of loss of gases at the epigenetic stage.

To determine the peculiarities of the chemical composition and concentrations of gases and bituminous matter in young basalts of the mid-oceanic ridge, we studied all structural-petrographic varieties of rocks from Holes 395 and 396 (see Chapters 7 and 8, this volume).

Gas extracts were obtained from 2-gram samples crushed in hermetically sealed argon-filled chambers. The gases were analyzed chromatographically. Lowboiling gases $\left(\mathrm{He}, \mathrm{H}_{2}, \mathrm{~N}_{2}, \mathrm{O}_{2}, \mathrm{CO}_{2}, \mathrm{CO}_{4}\right)$ were determined by Device LKHM-7A equipped with a catarometer. Very low hydrocarbon contents were determined using Device VX-2 with a flame-ionization detector; the threshold of sensitivity of this device was $10^{-5}$ per cent by volume. The bitumen extracts were studied by the luminiscence technique. Bitumen was extracted from micro-samples of the same material, using the cold extraction method, followed by treatment with chloroform and alcohol-benzol. The distribution of bitumens was studied on fresh surfaces of samples and during their disintegration was studied using an ultraviolet microscope. Examination of the fresh surfaces enabled us to determine associations of bitumens and gases in open cracks, and in spaces between crystals and grains of rocks. Bitumens in minerals were studied on the individual grains of crushed samples.

The gas content in rocks (Table 1, Figure 1) is not high $\left(<1 \mathrm{~cm}^{3} / \mathrm{kg}\right)$, but is somewhat higher than in basalts of the islands of the southwestern sector of the Pacific Ocean and the Kuril Island arc. The gas content of rocks sharply increases when $\mathrm{CO}_{2}$ becomes predominant. The number of such samples, however, is not large (less than $10 \%$ of the samples studied). Accordingly, the chemical composition of gases of most basalts can be determined by measuring the amount of hydrogen and hydrocarbons. Unaltered basalts, gabbro, and serpentinized peridotites are characterized by the highest hydrogen and hydrocarbon contents. The effusive rocks, which are more or less altered, and brecciated rocks contain appreciably lesser amounts of these gases. The spectrum of hydrocarbons whose abundance exceeds the sensitivity threshold of the flame-ionization detector is narrow $\left(\mathrm{CH}_{4}, \mathrm{C}_{2} \mathrm{H}_{6}, \mathrm{C}_{2} \mathrm{H}_{4}\right.$, and $\mathrm{C}_{3} \mathrm{H}_{8}$ ). The relative content of methane homologs (mainly $\mathrm{C}_{2} \mathrm{H}_{4}$ and $\mathrm{C}_{3} \mathrm{H}_{8}$ ) in the most thoroughly studied samples reaches 10 per cent and more-i.e., the hydrocarbons are mostly "heavy." This is well illustrated in Figure 2a, where the spread of the ratio of $\mathrm{CH}_{4}$ to heavy hydrocarbons varies within two orders of magnitude, whereas the $\mathrm{CH}_{4}$ content is smaller. The influence of the petro-chemical composition of samples on the $\mathrm{CH}_{4}$ content and the ratio of $\mathrm{CH}_{4}$ to heavy hydrocarbons proves insignificant.

Hydrogen is more unevenly distributed in the basalt samples studied (Figure 2), but is not correlated with the petrochemical composition or rocks.

Thus, one can think of a distinct association of gases not in the matrix of a rock, but in its mechanical and crystalline defects, fractures or cracks, intercrystalline spaces, and other defects of structure.

Structural defects are especially evident in studying the distribution of the bituminous matter in rocks. In particular, a dispersed distribution of bitumens, those intensively desorbed only during decomposition of their mineral host, occurs in only 35 to 36 per cent of samples. In the rest, the predominant portion of bitumens desorbed by chloroform is present as "films" along fissures and in intercrystalline spaces, or is concentrated as condensed drops in vesicles. When the bituminous matter is being dissolved in chloroform, the drops (pores?) look like bubbles or gaseous bitumen inclusions.

The total amount of bitumens in the basalts studied is not great (Table 2). The rocks most enriched in bituminous matter are those that underwent relatively low-temperature processes of hydration (serpentinized peridotites). The next most enriched are those with a coarse-crystalline structure acquired in magma chambers (gabbros); these are followed by fine-grained to glassy basalts (doleritic, porphyritic, and aphyric basalts). Bitumens of the two first groups of rocks are heavily reduced carbonaceous compounds (the bitumen content of a chloroform extract of bitumen $\mathrm{A}$ is sometimes higher than that of the alcohol-benzol extract of bitumen A).

The relationships between the contents of the chloroform and the alcohol-benzol extracts of bitumen $\mathrm{A}$ in the basalts vary because of a very uneven (irregular) 

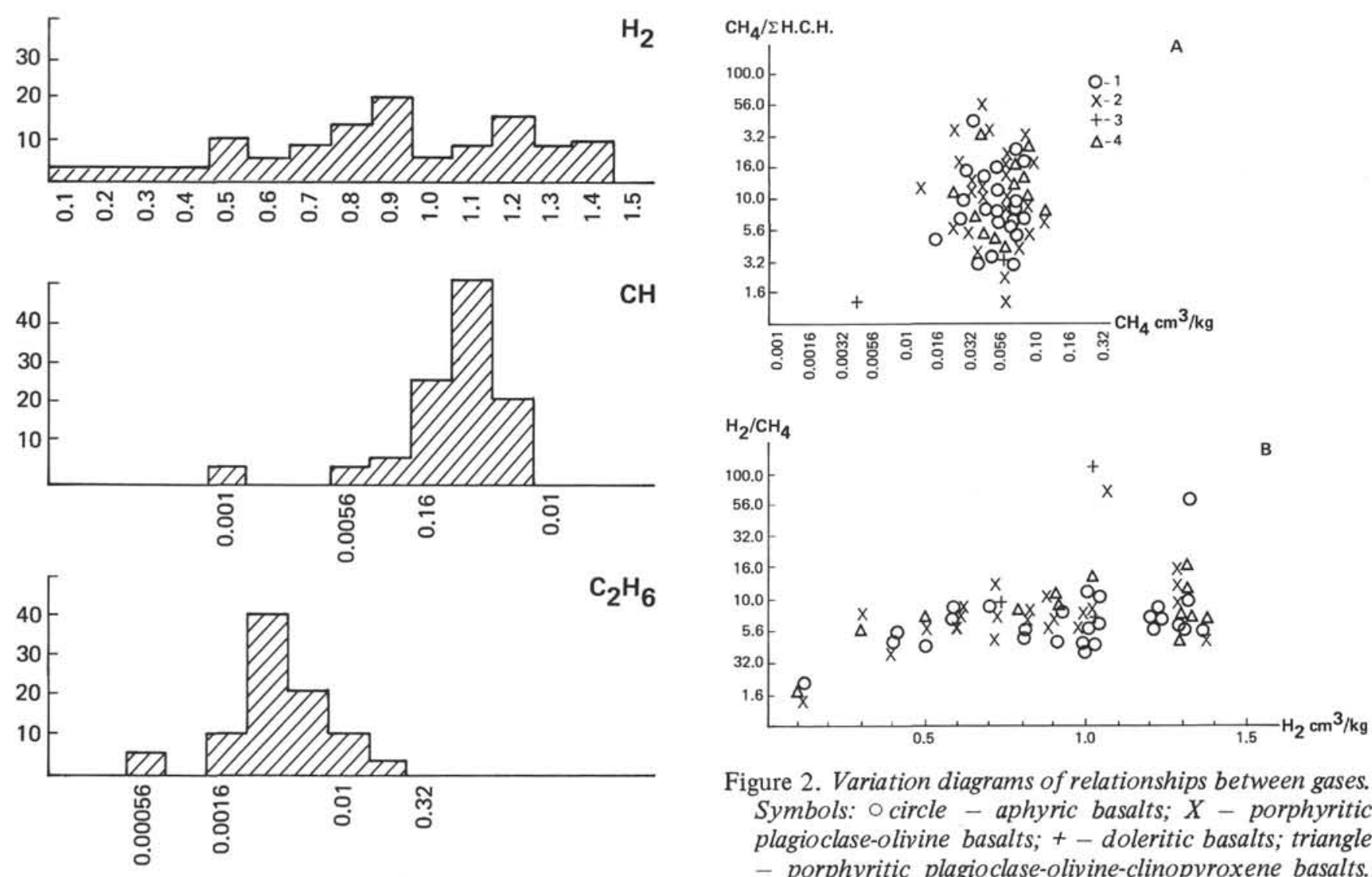

Figure 2. Variation diagrams of relationships between gases. Symbols: o circle - aphyric basalts; $X$ - porphyritic plagioclase-olivine basalts; + - doleritic basalts; triangle - porphyritic plagioclase-olivine-clinopyroxene basalts.
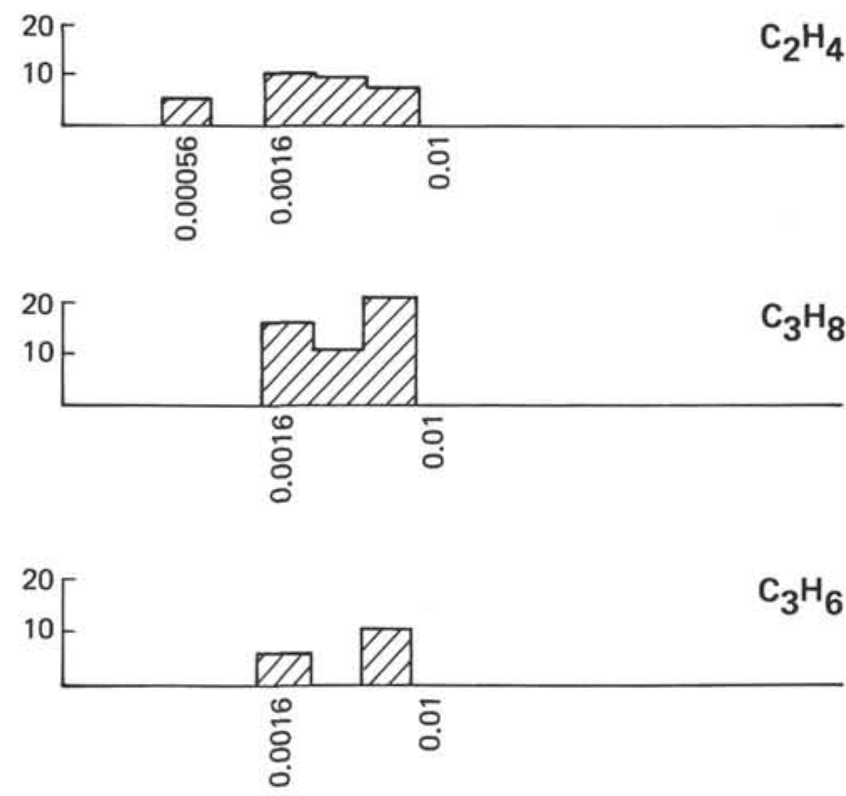

Figure 1. Histograms of gas distribution.

amount of oxidized bitumen in rocks. Accordingly, the histogram showing distribution of the chloroform extract of bitumen A is close to the Gauss distribution (Figure 3). Analysis of distribution of bituminous matter in individual samples (Table 3 ) shows that chloroform bitumen $\mathrm{A}$ is most frequently present as "cellular" (honeycomb) films, as finely dispersed forms, as microdrop inclusions, within and conforming
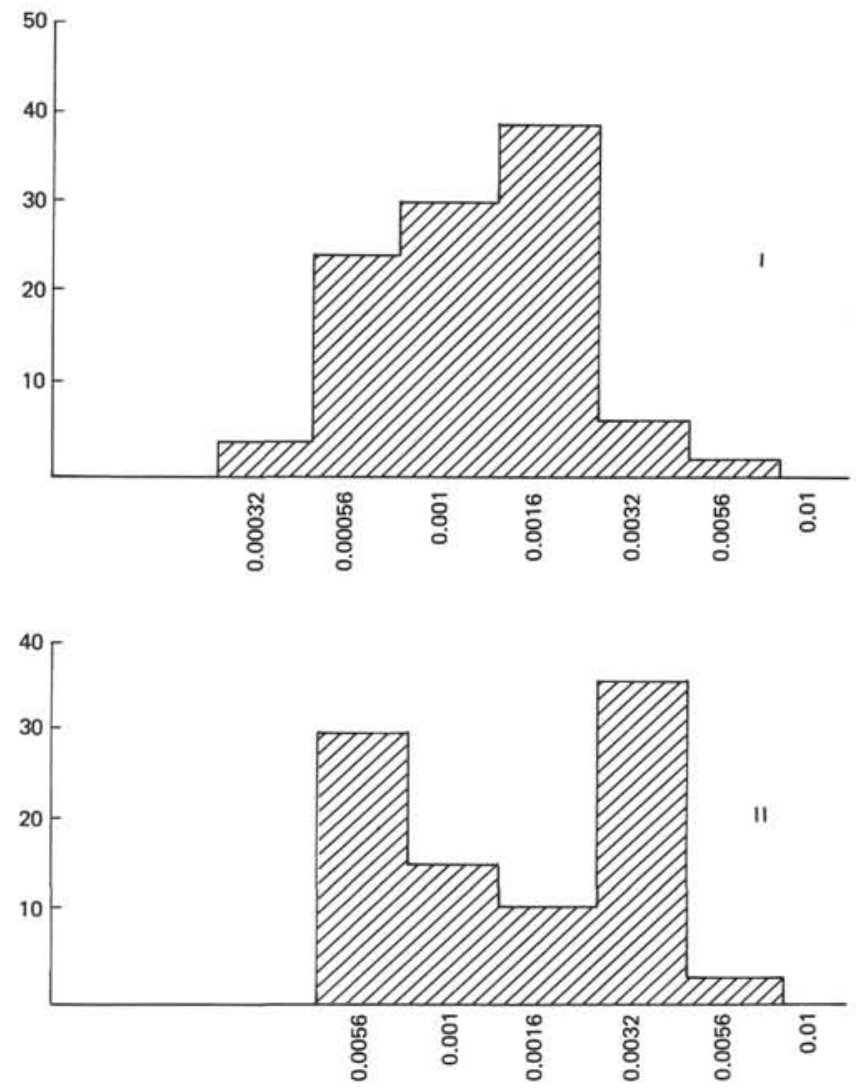

Figure 3. Histograms of distribution of chloroform bitumen $A$ (1) and alcohol-benzol bitumen A (II). 
TABLE 1

Chemical Composition and Gas Content in Rocks

\begin{tabular}{|c|c|c|c|c|c|c|c|}
\hline \multirow[b]{2}{*}{ Rock Type } & \multirow{2}{*}{$\begin{array}{l}\text { Number } \\
\text { of } \\
\text { Samples }\end{array}$} & \multicolumn{6}{|c|}{ Chemical Composition } \\
\hline & & $\mathrm{H}_{2}$ & $\mathrm{CO}_{2}$ & $\mathrm{CH}_{4}$ & $\mathrm{C}_{2} \mathrm{H}_{6}$ & $\mathrm{C}_{2} \mathrm{H}_{4}$ & $\mathrm{C}_{3} \mathrm{H}_{8}$ \\
\hline Peridotite, serpentinous & 2 & $\frac{13.97}{1.25(1.0-1.5)}$ & $\frac{83.90}{7.5(0.0-15.0)}$ & $\frac{1.34}{0.12(0.103-0.132)}$ & $\frac{0.67}{0.06(0.004-0.009)}$ & & $\frac{0.12}{0.0085}$ \\
\hline Gabbro & 1 & $\frac{89.7}{1.20}$ & 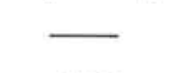 & $\frac{9.3}{0.132}$ & $\frac{0.7}{0.001}$ & $\frac{0.1}{0.002}$ & $\frac{0.4}{0.006}$ \\
\hline Dolerite & 4 & $\frac{13.93}{0.82(0.6-1.0)}$ & $\frac{84.97}{5.0(0.0-20.0)}$ & $\frac{0.85}{0.05(0.005-0.08)}$ & $\frac{0.17}{0.01(0.004-0.012)}$ & $\frac{0.035}{0.002(0.000-0.004)}$ & $\frac{0.035}{0.002(0.000-0.006)}$ \\
\hline Basaltic glass & 3 & $\frac{10.5}{0.60(0.3-0.9)}$ & $\frac{88.6}{5.0(0.0-15.0)}$ & $\frac{1.2}{0.07(0.051-0.08)}$ & $\frac{0.2}{0.01(0.003-0.008)}$ & 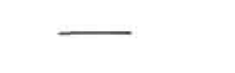 & $\frac{0.02}{0.001(0.000-0.004)}$ \\
\hline $\begin{array}{l}\text { Aphyric basalt, } \\
\text { variolitic }\end{array}$ & 2 & $\frac{9.82}{1.1(1.0-1.2)}$ & $\frac{89.62}{10.0(0.0-20.0)}$ & $\frac{0.62}{0.07(0.036-0.098)}$ & $\frac{0.04}{0.0055(0.005-0.006)}$ & $\longrightarrow$ & - \\
\hline $\begin{array}{l}\text { Aphyric basalt, } \\
\text { glassy }\end{array}$ & 8 & $\frac{15.4}{0.96(0.6-1.3)}$ & $\frac{84.8}{5.6(0.0-20.0)}$ & $\frac{0.9}{0.06(0.041-0.11)}$ & $\frac{0.1}{0.008}$ & $\frac{0.01}{0.0008}$ & $\frac{0.01}{0.0008}$ \\
\hline Aphyric basalt & 28 & $\frac{20.2}{0.9(0.1-1.4)}$ & $\frac{77.7}{3.5(0.0-45.0)}$ & $\frac{1.3}{0.06(0.02-0.103)}$ & $\frac{0.2}{0.01(0.001-0.017)}$ & $\frac{0.02}{0.001(0.000-0.006)}$ & $\frac{0.06}{0.003(0.000-0.048)}$ \\
\hline $\begin{array}{l}\text { Porphyritic basalt, } \\
\text { plagioclase }\end{array}$ & 1 & $\frac{10.7}{0.60}$ & $\frac{89.0}{5.0}$ & $\frac{0.5}{0.03}$ & $\frac{0.05}{0.003}$ & 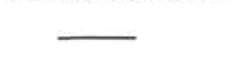 & - \\
\hline $\begin{array}{l}\text { Porphyritic basalt } \\
\text { plagioclase-olivine }\end{array}$ & 28 & $\frac{2.84}{0.5(0.1-1.5)}$ & $\frac{97.6}{17.0(0.0-65.0)}$ & $\frac{0.39}{0.07(0.015-0.132)}$ & $\frac{0.39}{0.007(0.000-0.012)}$ & $\frac{0.005}{0.001(0.000-0.007)}$ & $\frac{0.02}{0.004(0.000-0.032)}$ \\
\hline $\begin{array}{l}\text { Porphyritic basalt } \\
\text { plagioclase-olivine- } \\
\text { clinopyroxene }\end{array}$ & 16 & $\frac{17.42}{1.0(0.1-1.5)}$ & $\frac{81.53}{4.68(0.0-25.0)}$ & $\frac{1.04}{0.06(0.030-0.151)}$ & $\frac{0.104}{0.006(0.002-0.021)}$ & $\frac{0.016}{0.001(0.000-0.004)}$ & $\frac{0.016}{0.001(0.000-0.019)}$ \\
\hline $\begin{array}{l}\text { Porphyritic breccia of } \\
\text { plagioclase-olivine } \\
\text { basalt }\end{array}$ & 2 & $\frac{94.01}{1.1(1.0-1.2)}$ & 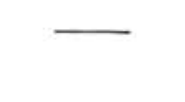 & $\frac{5.13}{0.064(0.037-0.091)}$ & $\frac{0.513}{0.006(0.001-0.011)}$ & $\frac{0.085}{0.001(0.000-0.002)}$ & $\frac{0.256}{0.003(0.000-0.006)}$ \\
\hline $\begin{array}{l}\text { Breccia of glassy } \\
\text { basalt }\end{array}$ & 1 & $\frac{95.13}{1.0}$ & - & $\frac{4.85}{0.052}$ & $\frac{0.02}{0.004}$ & - & - \\
\hline Basalt & 1 & $\frac{87.89}{0.90}$ & - & $\frac{10.45}{0.107}$ & $\frac{1.05}{0.011}$ & $\frac{0.28}{0.006}$ & $\frac{0.33}{0.007}$ \\
\hline
\end{tabular}

Note: Numerator: average content, \%. Denominator: average content and the limits, $\mathrm{cm}^{3} / \mathrm{kg}$.

TABLE 2

Bitumen Content in Rocks

\begin{tabular}{|c|c|c|c|c|}
\hline \multirow[b]{2}{*}{ Rock Type } & \multirow{2}{*}{$\begin{array}{l}\text { Number } \\
\text { of } \\
\text { Samples }\end{array}$} & \multicolumn{2}{|c|}{ Bitumens, Per Cent by Weight } & \multirow{2}{*}{$\begin{array}{l}\text { Ratio of Chloroform } \\
\text { Bitumen (A) to } \\
\text { Alcohol-Benzol } \\
\text { Bitumen (A) }\end{array}$} \\
\hline & & Chloroform A & Alcohol-Benzol & \\
\hline Peridotite-serpentinized & 2 & 0.0018 & 0.0006 & 3.0 \\
\hline Gabbro & 1 & 0.0018 & 0.0006 & 3.0 \\
\hline Dolerite & 4 & $\frac{0.0018}{0.0012-0.0024}$ & 0.0036 & 0.5 \\
\hline Basaltic glass & 3 & $\frac{0.00085}{0.00045-0.0012}$ & $\frac{0.0016}{0.0006-0.0036}$ & 0.5 \\
\hline $\begin{array}{l}\text { Basalt, aphyric } \\
\text { glassy }\end{array}$ & 2 & 0.0009 & $\frac{0.0021}{0.0006-0.0036}$ & 0.43 \\
\hline $\begin{array}{l}\text { Basalt, aphyric } \\
\text { variolitic }\end{array}$ & 8 & $\frac{0.0012}{0.0009-0.0024}$ & $\frac{0.0019}{0.0006-0.0036}$ & 0.63 \\
\hline Basalt, aphyric & 28 & $\frac{0.0014}{0.00045-0.0049}$ & $\frac{0.0016}{0.0006-0.0049}$ & 0.85 \\
\hline $\begin{array}{l}\text { Basalt, porphyritic, } \\
\text { plagioclase }\end{array}$ & 1 & 0.0024 & 0.0006 & 4.0 \\
\hline $\begin{array}{l}\text { Basalt, porphyritic, } \\
\text { plagioclase-olivine }\end{array}$ & 30 & $\frac{0.0021}{0.00045-0.009}$ & $\frac{0.0027}{0.0000-0.0049}$ & 0.8 \\
\hline $\begin{array}{l}\text { Basalt, porphyritic } \\
\text { plagioclase-olivine- } \\
\text { clinopyroxene }\end{array}$ & 16 & $\frac{0.0012}{0.0009-0.0024}$ & $\frac{0.00108}{0.0006-0.0036}$ & 1.1 \\
\hline $\begin{array}{l}\text { Breccia basalt- } \\
\text { porphyritic }\end{array}$ & 2 & 0.0024 & $\frac{0.0042}{0.0036-0.0049}$ & 0.63 \\
\hline $\begin{array}{l}\text { Breccia of basalt, } \\
\text { glassy }\end{array}$ & 1 & 0.0012 & 0.0018 & 0.66 \\
\hline Basalt & 1 & 0.0018 & 0.0036 & 0.50 \\
\hline
\end{tabular}

Note: Numerator: average content. Denominator: limits of contents, \%.

to the shape of light fraction films, etc. The gaseousfilmy phase of the chloroform bitumen A extract is common to small cracks. It is usually "sealed" with chloroform bitumen $\mathrm{A}$, and manifests itself in samples crushed to $<0.5 \mathrm{~mm}$, or in desorption of chloroform bitumen $\mathrm{A}$. The gaseous-filmy phase is frequently associated with dark aggregates with a peculiar size-of the order of $2 \mathrm{~mm}$ and smaller. The gaseous phase is associated with serpentine veins (in peridotites), or is in microvesicles, or is dissolved ("sealed") in the bituminous matter and boils during its dissolution. It also occurs in dark minerals, and is released after dissolving a chloroform constituent of bitumen A. Its properties sometimes approximate those of condensates.

Thus, basalts of the Mid-Atlantic Ridge contain gases mostly of the hydrocarbon-hydrogen composition. Gases constitute less than $1 \mathrm{~cm}^{3} / \mathrm{kg}$ of fresh rocks, but the amount becomes considerably higher if $\mathrm{CO}_{2}$ is predominant in the gas composition. In most samples the main component of gases is hydrogen. The hydrocarbons in gases of the basalts comprise a relatively narrow spectrum: they are represented mostly by $\mathrm{CH}_{4}$, $\mathrm{C}_{2} \mathrm{H}_{6}, \mathrm{C}_{2} \mathrm{H}_{4}, \mathrm{C}_{3} \mathrm{H}_{8}$, and $\mathrm{C}_{3} \mathrm{H}_{6}$. The amount of $\mathrm{CH}_{4}$ varies slightly, but the ratio of $\mathrm{CH}_{4}$ to heavy hydrocarbons varies considerably because of sharp fluctuations in the abundances of heavy hydrocarbons. Accordingly, the value of the ratio of the chloroform extract of bitumen $\mathrm{A}$ to the alcohol-benzol extract of bitumen A varies appreciably. Rocks that underwent relatively low temperature hydration (serpentinization in peridotites, 
TABLE 3

Content, Composition, and Structure of Bituminous Matter and Its Relationships With the Gaseous Phase in Individual Samples

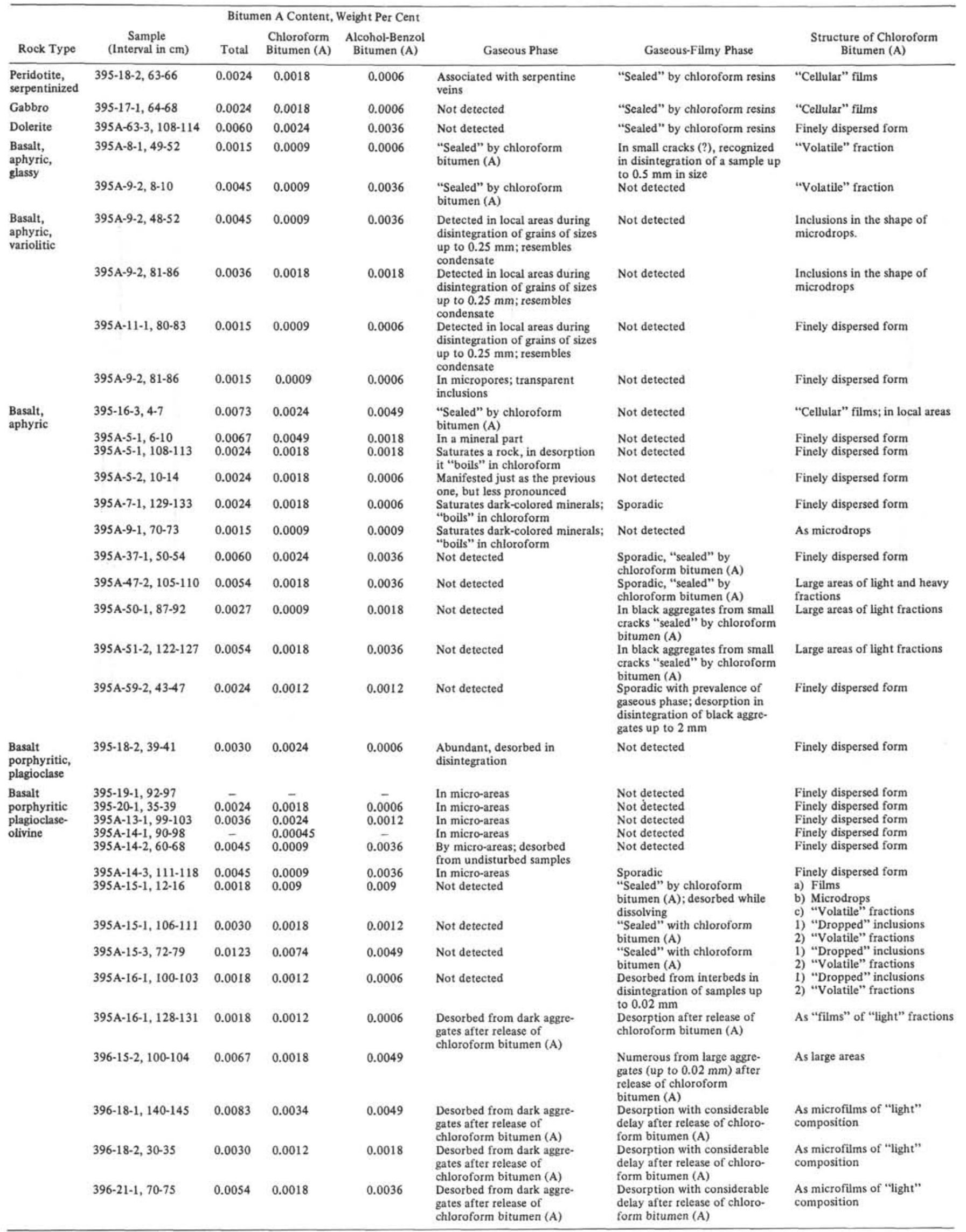


zeolitization, etc., in basalts) as well as coarsely crystalline rocks (gabbro), are characterized mostly by reduced bituminous matter. The total content of bituminous matter varies within one and one and a half orders of magnitude (from 0.00045 to $0.009 \%$ by weight). Morphologically, bituminous matter is represented by "filmy" forms associated with tiny cracks, by inclusions in the shape of microdrops and by dispersed-scattered forms in defects of crystals.

Thus, the chemical compositions of gases contained in basalts and their concentrations do not depend upon the chemical compositions of primary melts (if these vary within basaltic formations), but depend on the form of volcanic manifestation (extrusive, intrusive) and the degree of epimagmatic changes of rocks (alteration, serpentinization).

\section{REFERENCES}

Voitov, G. I., Shirokova, I. Ya., Sobolev, S. F., Zolotarev, B. P., 1970. On chemism of gases of Quaternary basaltoids of the Major Kuril arc, Doklady Akadem. Nauk SSSR, v. 190 , no. 2, p. $443-445$.

Zolotarev, B. P., Voitov, G. I., and Cherevichnaya, A. F., 1976. On gases of young basaltoids of some islands of the south western sector of the Pacific Ocean, Doklady Akad. Nauk SSSR, v. 229, no. 3, p. 721-724. 